\title{
Developing a software calculating fabric consumption of various bathrobe models
}

\author{
DOI: $10.35530 / I T .069 .05 .1550$
}

\section{REZUMAT - ABSTRACT}

\section{Dezvoltarea unui software de calculare a consumului de țesătură pentru diferite modele de halat de baie}

\begin{abstract}
Având în vedere cererile clienților și dinamica sectoruuil textil, ar trebui stabilite prețuri corecte în foarte scurt timp atunci când clienții le solicită pentru diferite stiluri de îmbrăcăminte. Clienții solicită adesea oferte de preț de la producătorii de îmbrăcăminte. În acest caz, producătorul de îmbrăcăminte trebuie să se miște rapid și precis pentru a determina consumul unitar al confecției. Este foarte important să se cunoască costul corect al țesăturii în stabilirea prețului produsului de îmbrăcăminte care urmează să fie creat. În general, costul țesăturii utilizate în articolele de îmbrăcăminte reprezintă 60-70\% din costul total. Producătorii își asumă riscuri atunci când stabilesc prețul îmbrăcămintei pe baza consumului aproximativ al tesăturilor. Toleranța la consumul de tesături poate fi luată mai mult ca un beneficiu, dar atunci comanda nu poate fi plasată de client din cauza prețului ridicat. În sistemele CAD, calculul consumului de țesături nu se poate face cu ușurință. În cadrul acestei cercetări, software-ul a fost dezvoltat pentru a calcula rapid consumul pe unitatea de îmbrăcăminte. Materialul pentru modelele de halat de baie a fost selectat și s-au folosit datele de la o fabrică care produce halate de baie. Rezultatele programului, dezvoltate împreună cu software-ul, sunt comparate cu cifrele experimentale. Astfel a fost posibil să se determine consumul de țesătură cu o precizie de $98,2 \%$ într-un timp foarte scurt, prin utilizarea sistemului dezvoltat $\left(R^{2}>0,982\right)$.
\end{abstract}

Cuvinte-cheie: consum de țesătură, determinare rapidă a prețurilor, raport de utilizare a țesăturii, software

\section{Developing a software calculating fabric consumption of various bathrobe models}

Considering the customer requests and speed in the textile sector, very fast and accurate pricing should be done when the customers ask for very urgent prices for different styles. Customers often ask for sample pricing from apparel manufacturers. In this case, the garment manufacturer has to move quickly and accurately in determining the unit consumption of the garment. It is very important to know the correct fabric cost in pricing the garment to be produced. In general, the cost of fabric in garments accounts for $60-70 \%$ of the total cost. Manufacturers take risks when pricing the garment with the approximate fabric consumption. Fabric consumption tolerance can be taken higher to be a benefit, but then the order may not be placed by the customer due to high price. In CAD systems, calculation of fabric consumption can not be done easily. In this research, the software has been developed to calculate the unit usage of a garment quickly. Bathrobemodels were selected as a material and the data of a factory that produces bathrobe was used. The results of the program, which is developed with the software, are compared with the experimental figures. As a result, it was possible to determine fabric consumption with a reliability of $98.2 \%$ in a very short time by using the developed system $\left(R^{2}>0.982\right)$.

Keywords: fabric consumption, faster pricing, fabric utilization ratio, software

\section{INTRODUCTION}

In textile industry, where customers ask for very urgent prices, companies have to inform them the accurate prices in a very short time. Especially in the sectors such as the apparel sector where high competition and variable factors are intensive, the use of effective production methods has become compulsory [1]. Fabric is generally the most significant factor in costing of garment. Fabric accounts for 60 to $70 \%$ of the total cost of basic-styled garments. The cost of fabric depends on the type of fabric is going to be usedto make the garment.

The fabric consumption of a garment is affected by the model, the measurements, the fabric width, and the size breakdown. Even for the same garment, the fabric consumption can vary in different fabric widths [2]. The garment manufacturer has to know the fabric consumption to be able to calculate the fabric cost of the garment and this is very important to make the correct costing, in today's world where the competition between the companies is highly increased. When the fabric width is known for a particular style, the length of the fabric to produce this style is called fabric consumption. Yesilpınaret al. have developed the software that enables the fabric consumptions of different shirt models to be estimated in a speedy way [3], [6]. Similarly, the software developed enables the estimation of fabric consumptions of different trouser models in a speedy way [4]. For cost and pricing purposes, Değirmenci and Çelik designed a computer program that helps calculate the unit costs of knitted fabrics [5]. A software has been developed using the Microsoft Visual Basic 6.0 programming language for clothing garment expense (tshirt models) for knitted garment enterprises. After the waste allowance is added on to the fabric yardage taken 
from the system, the total need for the order is determined [7]. Khalilov and Bozkurt have developed a software using Microsoft Access 2003, VBA and SQL programming language, which calculates pants fabric cost for manufacturers that produce denim pants [8]. Vuruskan has studied production parameters in knitted garment manufactures and prepared a computer program that calculates unit cost of 13 different clothes styles (t-shirt, jacket, athlete, skirt, blouse). The system using MySQL as a database computes the product cost in terms of user input data and archive information [9].

It is extremely important that the fabric is used efficiently. Various studies have been done to determine the use of fabric and to reduce losses. $\mathrm{Ng}$, Hui and Leaf aimed to estimate the loss of fabric in the laying process by developing a mathematical model. They separated the fabric losses into two groups, one inside and one inside the marker, and they created a mathematical formula by using the parameters used in the cutting plan and the factors which affect the fabric spreading in manufacturing [10]. Baykal and Göçer have compared the process counts and durations, cutting plan productivity, tape efficiencies and second quality ratios for different fabrics and different models during a garment operation [11].

Computer programs and softwares are widely used in order to find solutions to problems experienced in textile, ready-to-wear and fashion. Artificial Neural Networks, Fuzzy Logic, Genetic Algorithms and a Hybrid Planning Processes have been used to reduce fabric usage, mold development, analyzing and improving faulty fabrics in garment sector [12-17]. CAD/CAM systems provide significant advantages to apparel manufacturers. Hands et al. have experimentally proven in that the CAD system increases the rate of use of fabric usage and shortens the duration of pattern preparation [18, 19].

Antemie, et alhave developed a new method and emphasized the improvement on the stability of teoretical estimations regarding material consumption for textile products by adding this new method to computer assisted technical design [20].

This study was carried out to determine the unit fabric consumption of different bathrobe models by using computer programme. The program developed to calculate bathrobe fabric usage is explained. Therefore, first of all, the fabric consumption of bathrobe models is determined practically by the CAD system. In the end, the results of the software are compared with the actual fabric consumptions of the CAD system.

\section{MATERIAL AND METHOD}

\section{Material}

The materials of this research consist of bahthrobe models, fabrics, measurement charts, Konsan CAD system and computer programme which we created by using software. A garment manufacturing company which produce t-shirt, skirt, dress, tovel, bathrobe and which use quite a lof of different kinds of woven fabric is selected to take the actual unit fabric consumption of any style.

The selected company has a production capacity of 30,000 units a day. The company exports $95 \%$ of its products to European countries. Experimental studies related to the research patterns were made in the Konsan CAD system. The preparation of this research has taken 18 months together with the company. The company's process of calculating fabric consumption has been examined in the pattern department depending on the styles requested by the customers. The information required to determine the fabric consumption of a garment required for pricing has been arranged and classified. Information such as the order number of each bathrobe model, technical specifications, measurement charts, size breakdown, fabric usage rate and fabric width were analyzed. A total of 3042 purchase order, which consist of bathrobe product groups in various models, were included in the research. Software has been developed for the quick calculation of fabric consumption of a new style by using the previous marker plans. In total 3042 marker plans have been used.

\section{Method}

After all the information about the marker plan of a specific style is entered into the computer, the programming language Microsoft Access 2013, Microsoft Excel 2013, Visual Studio 2012, C \# (as encoding language), SQL Server 2014 and SQL (Structured Query Language) were used to calculate the fabric consumption in the requested size. In the evaluation of fabric consumption, two different metric values were considered.

i. Practical metrics obtained using CAD system;

ii. Theoretical unit obtained by computer software.

The actual fabric consumption and marking efficiency (fabric utilization rate) obtained from marker in the $\mathrm{CAD}$ system is taken into consideration for each model. The marker efficiency of the fabric can be seen in the marker layout in CAD system.

After the pattern layouts are made on the CAD screen, the unit fabric consumption for size $M$ is calculated according to the following equation.

$$
\text { Unit Fabric Consumpiton }(m)=L(i) / \sum S(i)
$$

where $L(i)$ is the $i^{\text {th }}$ marker length, and $\sum S(i)$ is the $i^{\text {th }}$ total size in the marker.

Five bathrobe models, the most produced in the company, were examined in the study. These are kimono, shawl collar, single hooded, child and double hooded bathrobes. Some bathrobe models are shown in figure 1.

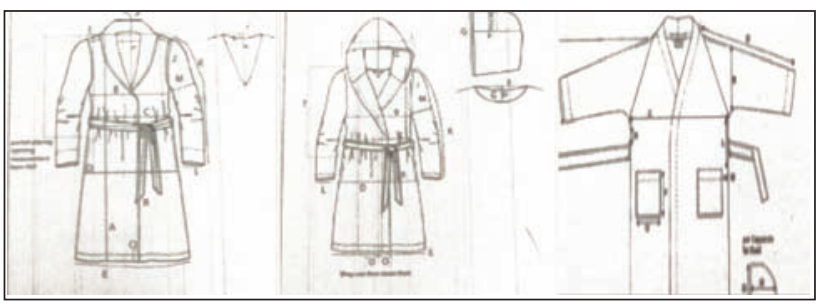

Fig. 1. Shawl collar, single hooded, child bathrobe models 


\begin{tabular}{|c|c|c|c|c|c|c|c|c|c|c|c|}
\hline \multirow{2}{*}{$\begin{array}{l}\text { Pattern } \\
\text { ID }\end{array}$} & \multirow{2}{*}{$\begin{array}{c}\text { Pattern } \\
\text { no. }\end{array}$} & \multirow{2}{*}{$\begin{array}{l}\text { Pattern } \\
\text { name }\end{array}$} & \multirow{2}{*}{$\begin{array}{l}\text { Model } \\
\text { type }\end{array}$} & \multirow{2}{*}{$\begin{array}{c}\text { Measurement } \\
\text { point }\end{array}$} & \multicolumn{4}{|c|}{ Size breakdown } & \multirow{2}{*}{$\begin{array}{c}\text { Size } \\
\text { name }\end{array}$} & \multirow{2}{*}{ Size } & \multirow{2}{*}{$\begin{array}{c}\text { Unit Fabric } \\
\text { Consumption } \\
(\mathrm{m})\end{array}$} \\
\hline & & & & & Size_1 & Size_2 & Size_3 & Size_4 & & & \\
\hline 16,00 & ZC-1000- & $267-1000$ & $\begin{array}{c}\text { Double } \\
\text { Hooded } \\
\text { Bathrobe }\end{array}$ & Hem width & 140,00 & 152,00 & NULL & NULL & Size_1 & $M / L$ & 3,05 \\
\hline 16,00 & ZC-1000- & $267-1000$ & $\begin{array}{c}\text { Double } \\
\text { Hooded } \\
\text { Bathrobe }\end{array}$ & Hem width & 140,00 & 152,00 & NULL & NULL & Size_2 & $\mathrm{L} / \mathrm{XL}$ & 3,42 \\
\hline 16,00 & ZC-1000- & $267-1000$ & $\begin{array}{l}\text { Double } \\
\text { Hooded } \\
\text { Bathrobe }\end{array}$ & Length & 105,00 & 113,00 & NULL & NULL & Size_1 & $M / L$ & 3,05 \\
\hline 16,00 & ZC-1000- & $267-1000$ & $\begin{array}{c}\text { Double } \\
\text { Hooded } \\
\text { Bathrobe }\end{array}$ & Length & 105,00 & 113,00 & NULL & NULL & Size_2 & $\mathrm{L} / \mathrm{XL}$ & 3,42 \\
\hline 16,00 & ZC-1000- & $267-1000$ & $\begin{array}{c}\text { Double } \\
\text { Hooded } \\
\text { Bathrobe }\end{array}$ & Chest $1 / 2$ & 62,00 & 68,00 & NULL & NULL & Size_1 & $M / L$ & 3,05 \\
\hline 16,00 & ZC-1000- & $267-1000$ & $\begin{array}{c}\text { Double } \\
\text { Hooded } \\
\text { Bathrobe }\end{array}$ & Chest $1 / 2$ & 62,00 & 68,00 & NULL & NULL & Size_2 & $\mathrm{L} / \mathrm{XL}$ & 3,42 \\
\hline 16,00 & ZC-1000- & $267-1000$ & $\begin{array}{l}\text { Double } \\
\text { Hooded } \\
\text { Bathrobe }\end{array}$ & Arm length & 75,00 & 79,00 & NULL & NULL & Size_1 & $M / L$ & 3,05 \\
\hline 16,00 & ZC-1000- & $267-1000$ & $\begin{array}{l}\text { Double } \\
\text { Hooded } \\
\text { Bathrobe }\end{array}$ & Arm length & 75,00 & 79,00 & NULL & NULL & Size_2 & $\mathrm{L} / \mathrm{XL}$ & 3,42 \\
\hline
\end{tabular}

\section{Computer program}

In the research, original data of 313 marker plans from 3042 marker plans were recorded in the database of the developed program. The steps followed when developing the software are as follows.

1) The marker plan inputs in the company's database were arranged in Excel format in table 1. As input data; pattern number, pattern name, measurement chart, size breakdown, size name, model definition, fabric type, CAD productivity and actual fabric consumption were kept in a special format prepared during 1.5 years. Then the form was transformed to table 2. Table 2 (target_table) is an example table in which a portion of the data is contained.

2) The Excel data shown in table 1 was transferred to a database named "unit fabric consumption" created in SQL Server 2014. Figure 2 shows the SQL Server Management Studio database and tables screen.

3) Three pieces "view"s were created to use the code to be written with SQL. "View"; are query interfaces that can be used to create new virtual output tables using relationships between these tables. A sample "view" and columns are shown in figure 3.

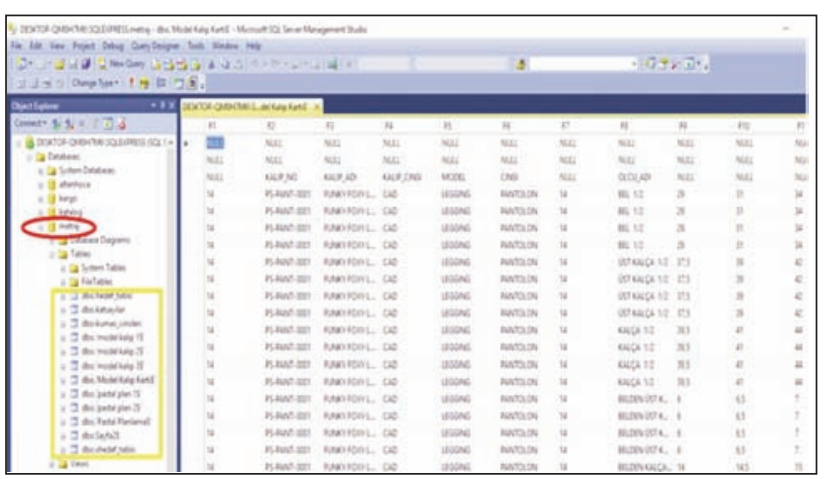

Fig. 2. SQL Server Management Studio database and tables screen
4) After 3 views were created, they were extracted with the following "cursor" written in the SQL language and incomplete or inconsistent data were eliminated. The data that can be used in the estimation were transferred to the file named "target_tablo" based on the inputs used in the written program. Cursor is a database system structure that is written in SQL language and enables to process the data by examining line by line. With this process, data of 313 marker plans from 3042 were obtained. Screenshot of a section of the cursor code written in SQL Language is shown in figure 4.

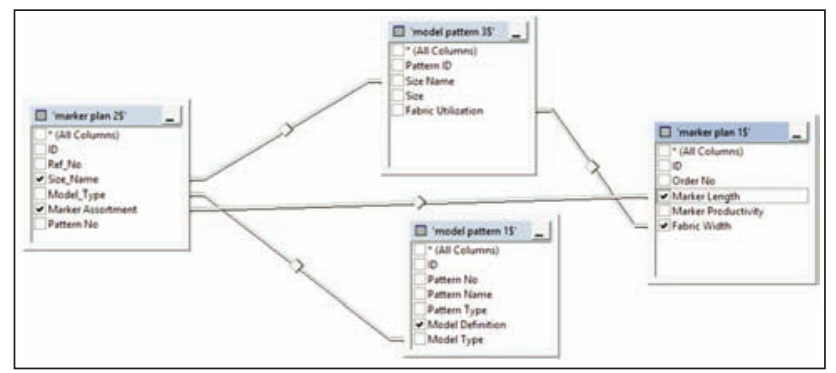

Fig. 3. The sample "View" to be used by SQL written code

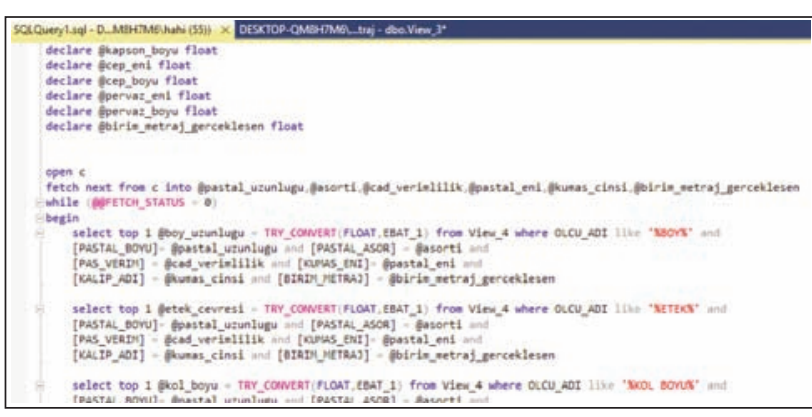

Fig. 4. Screenshot of a section of the cursor code written in SQL Language 


\begin{tabular}{|c|c|c|c|c|c|c|c|c|c|c|c|c|c|c|c|c|c|c|}
\hline 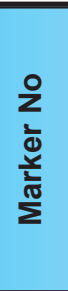 & 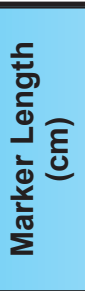 & 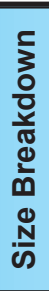 & 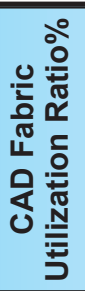 & 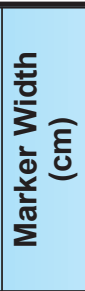 & 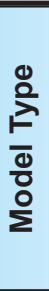 & 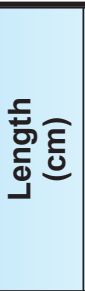 & 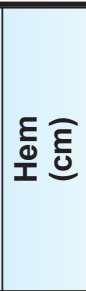 & 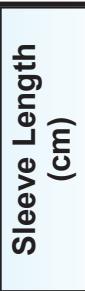 & $\frac{\circlearrowleft}{\frac{0}{\circ}}$ & 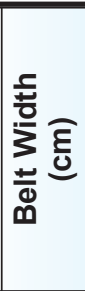 & 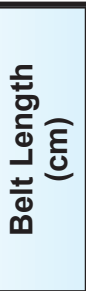 & 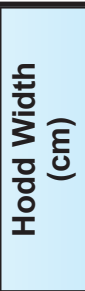 & 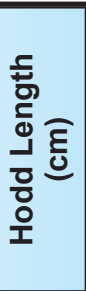 & 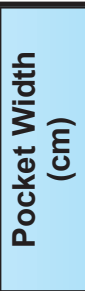 & 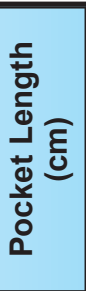 & 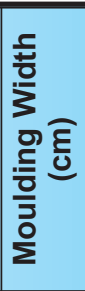 & 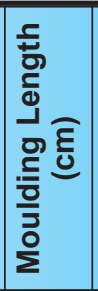 & 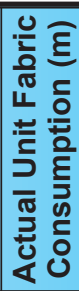 \\
\hline 669 & 241 & 1 & 88 & 157 & 2 & 60 & 95 & 29,5 & 0 & 3,5 & 130 & 22,5 & 28,5 & 14 & 15 & 0 & 0 & 1,26 \\
\hline 670 & 241 & 1 & 88 & 157 & 2 & 66 & 103 & 34 & 0 & 3,5 & 140 & 23,5 & 29,5 & 14 & 15 & 0 & 0 & 1,43 \\
\hline 671 & 241 & 1 & 88 & 157 & 2 & 70 & 109 & 37,5 & 0 & 3,5 & 150 & 24 & 30 & 15 & 16 & 0 & 0 & 1,58 \\
\hline 672 & 241 & 1 & 88 & 157 & 2 & 73 & 117 & 40 & 0 & 3,5 & 150 & 24,5 & 30,5 & 15 & 16 & 0 & 0 & 1,68 \\
\hline 673 & 241 & 1 & 88 & 157 & 2 & 85 & 126 & 0 & 0 & 0 & 150 & 25 & 31 & 16 & 17 & 0 & 0 & 1,8 \\
\hline 674 & 257 & 2 & 89,8 & 157 & 2 & 60 & 95 & 29,5 & 0 & 3,5 & 130 & 22,5 & 28,5 & 14 & 15 & 0 & 0 & 1,26 \\
\hline 675 & 257 & 2 & 89,8 & 157 & 2 & 66 & 103 & 34 & 0 & 3,5 & 140 & 23,5 & 29,5 & 14 & 15 & 0 & 0 & 1,43 \\
\hline 676 & 257 & 2 & 89,8 & 157 & 2 & 70 & 109 & 37,5 & 0 & 3,5 & 150 & 24 & 30 & 15 & 16 & 0 & 0 & 1,58 \\
\hline
\end{tabular}

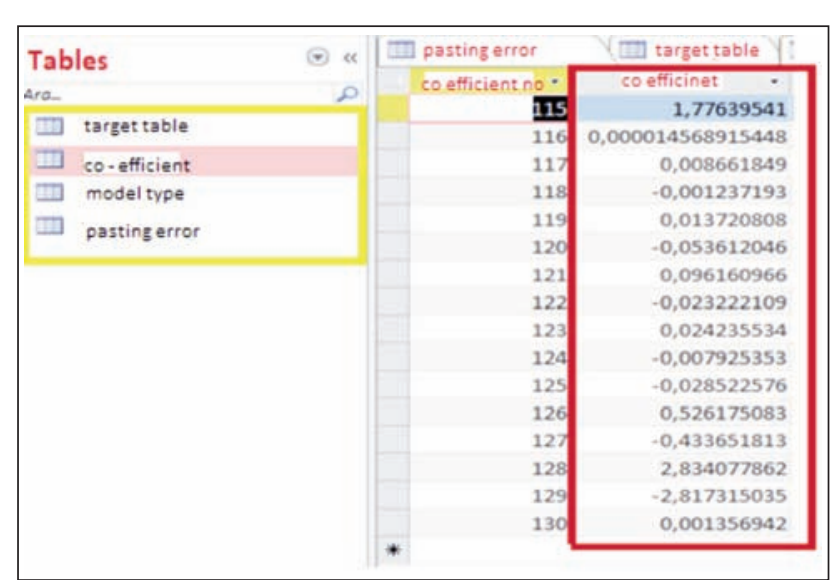

Fig. 5. Screenshot of the database and "coefficient" tables used by the program

5) Thousands of data were parsed by means of a cursor and the necessary data were retrieved again, then the data were transferred back to in Excel (table 2 - target_table). For some sections the data were not available due to the bathrobe model.

6) In Excel, a regression analysis was performed to determine the relationship between input data and output data. As a result of the regression analysis, the coefficient relation between output and inputs is determined as shown in figure 5 . The coefficient values for the inputs and outputs obtained at the end of the regression analysis are transferred to the previously prepared target table. Formula 2 contains the equation for the regression analysis.

Predicted fabric consumpiton $(m)=C A D$ Fabric Utilization Ratio * Coefficient [2][2] (Column 2 of the 2nd column of the coefficient table) + Marker Width * Coefficient [3][2] + Model Type * Coefficient [4][2] + Length * Coefficient [5][2] + Hem * Coefficient [6][2] + Sleeve Length * Coefficient [7][2] + Arm Hole * Coefficient [8][2] + Belt Width * Coefficient [9][2] + Belt Length * Coefficient [10][2] + Hood Width * Coefficient [11][2] + Hood Length * Coefficient [12][2] + Pocket Width * Coefficient [13][2] + Pocket Length

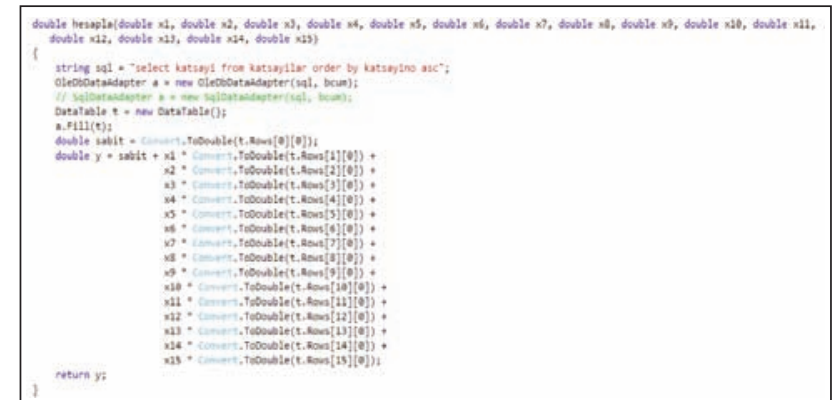

Fig. 6. Screenshot of the function which the program uses in estimation

* Coefficient [14][2] + Moulding Width * Coefficient [15][2] + Moulding Length*Coefficient[16][2] + Coefficient [1][2] .

7) The data in the "coefficients" table are used to transform the input form to the output form and the estimated value is calculated by the function written in the $\mathrm{C}$ \# programming language by creating the estimation formula in figure 6.

8) This database in Access is finally delivered with the program written in $\mathrm{C}$ \# programming language in Visual Studio 2012.

\section{FINDINGS}

Estimation can be achieved on the main screen of figure 6 of the developed program. The data for the bathrobe to be estimated are entered to program in order to make estimations. It was initially tested with real data at $20 \%$, which were not used in testing the program generated with real data. The estimates of the program have been found to be very close to the actual values (98.25\%).

For example, when the marker length, size breakdown, estimated CAD efficiency, fabric width and bathrobe measurements for double-hooded bathrobe model shown on figure 7 were entered then the "Calculate" button was pressed, the estimated unit fabric consumption in the seconds is calculated as $1.47 \mathrm{~cm}$. The actual fabric consumption for this 


\begin{tabular}{|c|c|c|c|c|c|}
\hline $\begin{array}{c}\text { Model } \\
\text { number }\end{array}$ & $\begin{array}{c}\text { Model } \\
\text { definition }\end{array}$ & $\begin{array}{c}\text { Software Fabric } \\
\text { Comsumption } \\
(\mathbf{m})\end{array}$ & $\begin{array}{c}\text { Actual Fabric } \\
\text { Comsumption CAD } \\
(\mathbf{m})\end{array}$ & Error $(\mathbf{m})$ & Error $(\%)$ \\
\hline 1 & Kimono & 1,026 & 1,050 & 0,024 & 2,25 \\
\hline 2 & Shawl-Collar & 1,166 & 1,260 & 0,94 & 7,4 \\
\hline 3 & Child Bathrobe & 1,016 & 1,030 & 0,014 & 1,26 \\
\hline 4 & Double Hooded Bathrobe & 3,959 & 3,980 & 0,021 & 0,50 \\
\hline 5 & Single Hooded Bathrobe & 2,290 & 2,270 & 0,02 & 0,89 \\
\hline
\end{tabular}

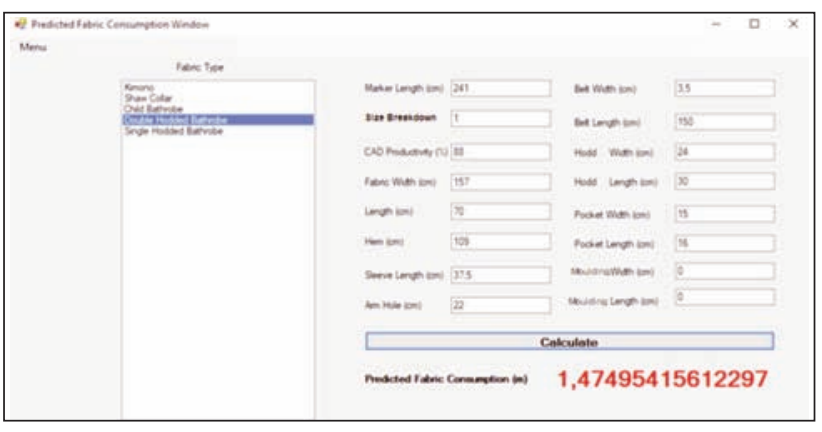

Fig. 7. Main Screen of the Program (Forecasting Screen)

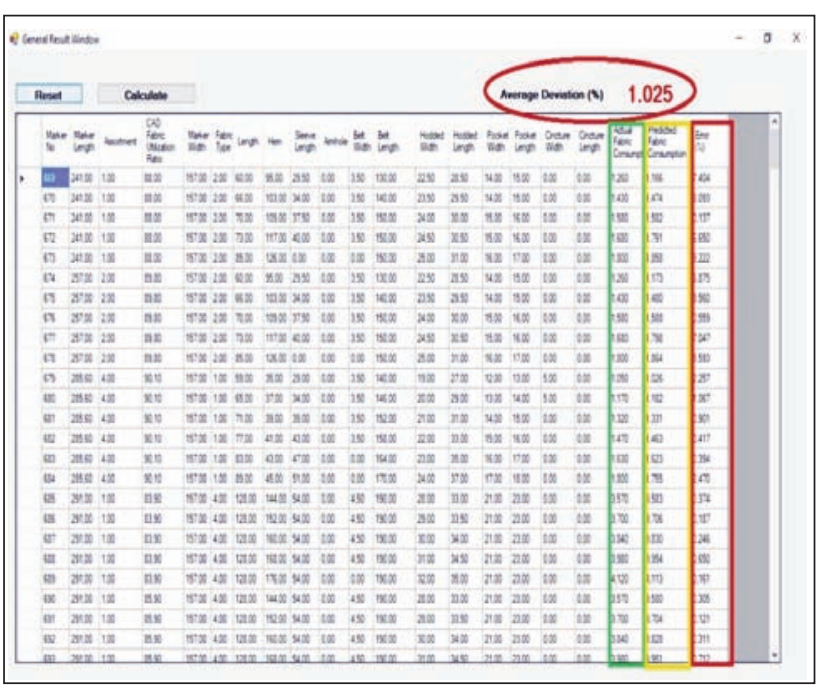

Fig. 8. Cumulative results display

bathrobe is $1.43 \mathrm{~cm}$. The estimation power for this example is $97.24 \%$.

In figure 8, a report was drawn showing the relationship between the actual data and the estimated values produced by the program. The average deviation of 313 marker plans is $1.025 \%$.

Figure 9 exhibits comparison of real values and estimation values of 35 piece bathrobes. While $x$-axis indicates fabric consumption results $(m), y$-axis indicates number of bahtrobe models.

The software results used in determining the unit fabric consumption for bathrobes and the comparison of the results with the CAD system and the correlation coefficient are given in table 3 for each model in from figure 2 (Batch Results Screen).

When all results are taken into consideration regarding estimation performance of the software, it was

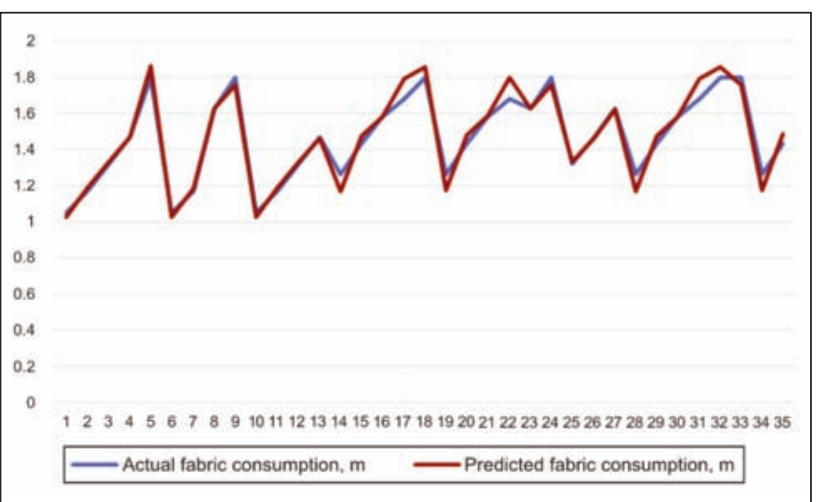

Fig. 9. Comparison of real values and estimated values given by the software

determined that the correlation between the real values and estimated values is the same as it was revealed by the high correlation coefficient of $\mathrm{R}=0.989$ in figure 9 .

Based on the regression coefficient in figure $9(R=$ 0.989), it could be observed that data have a linear structure, which suggests that estimation strength of the structured network was rather high.

\section{CONCLUSIONS}

The theoretical unit fabric consumption calculation obtained by estimation before production is necessary for order pricing and to be able to respond quickly to customer requests. Firms make estimations of fabric consumption for costing in different ways, taking advantage of their previous experience. However, this practice is depensioning the experience of the price maker and the accumulation of his previous work. Some details in pattern and size breakdown may be forgotten or overlooked and this may cause serious financial problems. It is aimed to shed light on the firm and the people working on this subject in the quantitative estimation study made for this purpose. When the software program is used;

- At the manufacturer's office, an archive will be created in which all the marker information is stored regularly. A new order with similar features will be able to determine fabric consumption and price in a short time using available information.

- In addition, since the fabric consumption change on different fabric widths entered in the system, the firm will be able to determine the optimum fabric width most efficiently and increase the productivity. 
It is a very important achievement to start production by determining the optimal fabric width for garment manufacturers.

- The amount of fabric required according to the order quantitiy can be determined and contributed to the planning.

- Estimating power of the program written in the research is $(\mathrm{R} 2>0.982)$. The reliability of the system is $98.25 \%$. Therefore, in a short period fabric consumption can be determined with a close approximation to the fact. In fact, fabric consump- tionthat can be determined by a long study can be determined in a few seconds via software.

In this research, a software was developed that calculates the fabric consumption of bathrobe models. Software that calculates the fabric consumption of other types of clothing, such as trousers, dresses, t-shirts and skirts, can be developed in a similar way.

\section{ACKNOWLEDGEMENT}

We thank HÜRSAN Tekstil San. Tic. A.Ş. for the support they provided in this research and enabling testing of the software developed.

\section{BIBLIOGRAPHY}

[1] Erdogan, M.C., Sen, G.A., Yuecel, O. (2007). Determining the product cost using the transportation method in clothing production. In: Textile and Apparel, 17 (2), pp. 132-139.

[2] Yeşilpınar, S. (2005). Research on determining the optimum fabric width in the production of denim pants, In: The Journal of Textiles and Engineer, Year: 12, Vol: 58, pp. 3-5.

[3] Yeşilpınar, S. \& Aytaç, V. (2009). An approach aimed at fabric consumption in shirt production. In: Textile Research Journal, 79 (5), pp. 461-467.

[4] Yeşilpınar, S., Aytaç, V., Khalilov, F., Bozkurt, L. (2009). Development of software that calculates the fabric consumption of garments in clothing factories, In: The Journal of The Textile Institute, 100 (7), pp. 626-632.

[5] Değirmenci, Z., Çelik, N. (2013). Devoloping a software to calculate the unit cost of the double-fleece knitted fabric, In: Journal of Textiles and Engineer, 20(92), pp. 49-58.

[6] Ak, D. (2009). Development of software that calculates the fabric consumption of various t-shirt models, In: Dokuz Eylül University, Department of Textile Engineering, Master Thesis, Turkey.

[7] Ören, Ş. (2004). Development of software that calculates fabric consumption in garment. In: DokuzEylül University, Department of Textile Engineering, Master Thesis, Turkey.

[8] Khalilov, F., and Bozkurt, L. (2005). Development of a software calculating fabric consumption of various pant models, In: Dokuz Eylül University, Department of Textile Engineering, Master Thesis, Turkey.

[9] Vuruşkan, A. (Temmuz 2005). Development a software about calculating the production parameters in knitted garment plant. In: Dokuz Eylül University, Department of Textile Engineering, Master Thesis, Turkey.

[10] Frency, Ng S.F., Hui, C.L.P. and Leaf, G.A.V. (1999). A mathematical model for predicting fabric loss during spreading, In: International Journal of Clothing Science and Technology, 11.2/3, pp. 76-83.

[11] Baykal, D.P., Göçer, E. (2012). The effect of fabric and model diversity to quality and productivity in clothing industry, In: Journal of Textiles and Engineer, 19: 87, pp. 15-23.

[12] Kim, H.S., Sung-Bae Cho, S.B. (2000). Application of interactive genetic algorihm to fashion design. In: Engineering Applications of Artificial Intelligence, 13, pp. 635-644.

[13] Mok, P.Y., C.K. Kwong, W.K. (2007). Optimisation of fault-tolerant fabric-cutting schedules using genetic algorithms and fuzzy set theory, In: European Journal of Operational Research 177, pp. 1876-1893.

[14] Yi Xiu, Zhen-Kai Wan and Wen Cao (2010). A constructive approach toward a parametric pattern-making model, In: Textile Research Journal 81(10), pp. 979-991.

[15] Wong, W.K. and Leung, S.Y.S. (2009). A hybrid planning process for improving fabric utilization, In: Textile Research Journal Vol. 79(18), pp. 1680-1695.

[16] Wong, W.K., Leung, S.Y.S. (2008). Genetic optimization of fabric utilization in apparel manufacturing, In: International Journal of Production Economics, 114(1), pp. 376-387.

[17] Patrick, C.L.H., Frency, S.F.N., \& Keith, C.C.C. (2000). A study of the roll planning of fabric spreading using genetic algorithms. In: International Journal of Clothing Science and Technology, 12 (1), pp. 50-62.

[18] Hands, C., Hergeth, H.H.A., \& Hudson, P. (1997). Marker making in small clothing companies - Part 1. In: International Journal of Clothing Science and Technology, 9 (2), pp. 154-165.

[19] Hands, C., Hergeth, H.H.A., \& Hudson, P. (1997). Marker making in small clothing companies - Part 2. In: International Journal of Clothing Science and Technology, 9 (2), pp. 166-176.

[20] Antemie, A., Harnagea, F., Popp, A. and Bruniaux, P. Developing original software designed to estimate consumption norms for textile products, using the method based on the sum of all rests. In: Industria Textila, 2013, vol. 64, issue 5, pp. 285-292.

\section{Authors:}

MIHRIBAN KALKANCI, İHSAN ÖZER

Pamukkale University, Denizli Vocational School of Technical Sciences, CamlaraltıMah.Fakülte Cad. No: 30 20160, Kınıklı/Denizli, Turkey

\section{Corresponding author:}

MIHRIBAN KALKANCI

e-mail: mkalkanci@pau.edu.tr 